\title{
Validation of processed animal proteins (mono-PAPS) in experimental diets for juvenile gilthead sea bream (Sparus aurata L.) as primary fish meal replacers within a European perspective
}

by Davies, S.J., Laporte, J., Gouveia, A., Salim, H.S., Woodgate, S.T., Hasaan, M.S., El-Haroun, E.R.

Copyright, publisher and additional Information: This is the author accepted manuscript. The final published version (version of record) is available online via Wiley. This article may be used for non-commercial purposes in accordance with Wiley Terms and Conditions for Self-Archiving.

Please refer to any applicable terms of use of the publisher.

DOI: $\underline{\text { https://doi.org/10.1111/anu.12846 }}$

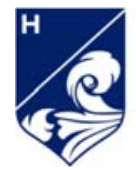

Harper Adams University

Davies, S.J., Laporte, J., Gouveia, A., Salim, H.S., Woodgate, S.T., Hasaan, M.S., El-Haroun, E.R. 2018. Validation of processed animal proteins (mono-PAPS) in experimental diets for juvenile gilthead sea bream (Sparus aurata L.) as primary fish meal replacers within a European perspective. Aquaculture Nutrition. 
1 Validation of processed animal proteins (mono-PAPS) in experimental diets for juvenile

2 gilthead sea bream (Sparus aurata L.) as primary fish meal replacers within a European

3 perspective

4

5 S. J. DAVIES ${ }^{a *}$, J. LAPORTE $^{\mathrm{b}}$, GOUVEIA, A $^{\mathrm{c}}$, S.M. WOODGATE $^{\mathrm{d}}$, M.S. HASSAAN \& E.

$6 \quad$ R. El-HAROUN

8 a HAU Aquaculture Centre, Department of Animal Production, Welfare and Veterinary 9 Sciences, Harper Adams University, Newport, Shropshire, UK

b School of Marine and Biological Sciences, University of Plymouth, Plymouth, PL48AA, Plymouth, UK

$13{ }^{\mathrm{c}}$ Departamento de Biologia, Faculdade de Ciências do Porto, Universidade do Porto, Rua do 14 Campo Alegre, 4169-007, Porto and CIMAR / CIIMAR - Centro Interdisciplinar de 15 Investigação Marinha e Ambiental, Rua dos Bragas 289, 4050-123, Porto, Portugal

d Beacon Research Ltd, Greenleigh, Kelmarsh Rd, Clipston Mkt. Harborough, LE16 9RX, UK

18 e Aquaculture Division, Fish Nutrition Laboratory, National Institute of Oceanography and 19 Fisheries (NIOF), Cairo, Egypt

$21 *$ Corresponding author: Prof. Dr Simon Davies

22 Email: sdavies@harper-adams.ac.uk 


\section{Abstract}

Experimental diets were formulated to evaluate a "pure" poultry meat meal (PMM)

26 source in diets formulated for juvenile gilthead sea bream (Sparus aurata L.). The digestible 27 protein contribution of fish meal in a control diet was substituted by 25,50 and $75 \%$ of a 28 processed poultry meat meal (PMM) on a digestible crude protein (DCP)_basis and by 5\% and $2910 \%$ for an enzyme treated feather meal (EFM) and also a spray-dried haemaglobin meal 30 (SDHM) respectively. In a consecutive trial, diets were designed to assess the value of a "pure"

31 (defatted) poultry protein substituting the fish meal (FM) protein content. Experimental diets 32 included: a control diet, two test diets where $75 \%$ of FM was replaced by a full fat PMM 33 (PMM75) or a defatted grade of PMM (dPMM75) and two test diets where 50\% of FM was 34 substituted for defatted PMM (dPMM50) or a 50:50 blend of soybean meal and defatted PMM $35(\mathrm{SBM} / \mathrm{dPMM})$ to produce a composite product This soybean/dPMM blend was tested to 36 enhance the nutritional value of this key plant ingredient commonly employed in sea bream 37 diets that can be deficient in specific amino acids and minerals. In the first trial, gilthead sea 38 bream grew effectively on diets containing up to the $75 \%$ replacement of FM attaining a mean 39 weight of $63.6 \mathrm{~g}$ compared to $67.8 \mathrm{~g}$ for the FM control fed group. For the consecutive trial, the 40 fishmeal based control diet yielded the highest SGR followed by dPMM50 and SBM/dPMM 41 blend inclusion but were not significant.

Carcass FA profiles of gilthead sea bream conformed to the expected changes in relation

43 to the dietary FA patterns, with the $18: 1 \mathrm{n}-9$ representative of the poultry lipid signature 44 becoming more apparent with PMM inclusion. The ratio of $n-3 / n-6$ fatty acids was greatly 45 affected in sea bream fed the full fat PMM at 75\% inclusion due to fish oil exclusion. 
De-fatted dPMM however allowed more of the fish oil to be used in the diet and

47 reducing this latter effect in sea bream carcass hence restoring the higher total omega-3 HUFA

48 fatty acids namely EPA \& DHA and n-3/n-6 ratio. It is concluded that poultry meat meal can be

49 modestly incorporated into formulated diets for seabream and can be used in conjunction with

50 soybean meal without any fundamental changes in performance and feed efficiency.

KEY WORDS: poultry meat meal, de-fatted meal, enzyme treated feather meal, spray-

53 dried haemoglobin meal, gilthead sea bream, growth, feed utilization, HUFA fatty acids (n-3/n546 ratio,

\section{Introduction}

The scope for replacing fish meal (FM) in feeds for commercially valuable fish species in

57 aquaculture is of prime importance to meet sustainable production in many regions of the world

58 (Hatlen, Jakobsen, Crampton, Alm, Langmyhr, Espe, \& Waagbø, 2015; Moutinho, Martínez-

59 Llorens, Tomás-Vidal, Jover-Cerdá, Oliva-Teles, \& Peres, 2017). Suitable alternative proteins

60 have been evaluated with much success, most notably those obtained from plant by-products

61 such as soybean meals (SBM), various legumes and pulses e.g. beans and peas (Drew,

62 Borgeson, \& Thiessen, 2007; Gatlin, Barrows, Brown, Dabrowski, Gaylord, Hardy, Herman,

$63 \mathrm{Hu}$, Krogdhal, Nelson, Overturf, Rust, Sealey, Skonderg, Souza, Stone, Wilson, \& Wurtele,

64 2007; Hardy 2010; Kumar, Sándor, Nagy, Fazekas, Havasi, Sinha, De-Boeck, 2016; Rostamian,

65 Eagderi, S., Masoudi, Salar \& Asadian, 2016; Novriadi, Spangler, Rhodes, Hanson \& Davis 66 2017).

67 In Europe, due to public concern and legislative control, limitations exist on exploiting 68 animal derived proteins and fats in aquafeeds (SECA 2010). This has been the case for over a 
69 decade, but specific category III sources (material derived from animals fit for human 70 consumption) are now allowed after recent approval by the European Food Safety Authority 71 (EFSA 2013). These currently include blood meal (BM) from porcine origin and now rendered 72 poultry by-products (PBM) are once again feasible in commercial fish diets within the European 73 Union (EU). Animal by-products are routinely available for use in compound diets for fish and 74 crustacean throughout the world (Bureau Harris, Bevan, Simmons, Azevedo \& Cho 2000; 75 Moutinho et al. 2017; El-Husseiny Hassan, El-Haroun, \& Suloma 2018). In the 1990's bovine 76 spongy encephalopathy (BSE) considered to be the major constraint of using animal by-product 77 in UK and Europe. The nutritional potential of by-products derived from poultry as secondary 78 protein sources in marine fish diets have been advocated in numerous studies to date. Since 79 then, there have been considerable progressions globally in the use of high quality low 80 temperature fish meal (LT FM's) and a new generation of processed animal by-products from 81 category III sources involving optimized temperature and pressure treatments with enzyme 82 hydrolysis. These have provided a prerequisite for more extensive nutritional trials involving 83 more balanced diet substitutions based on digestible protein, amino acids and energy basis. 84 Similarly, novel processes outlined by (Rebafka \& Kulshrestha 2009; El-Haroun, Azevedo \& 85 Bureau 2009; Abwao, Safina, Ondiba, Ogello, \& Obiero 2017) such as improved cooking and 86 drying temperatures similar to those used for FMs are a better strategy to improve the quality 87 and nutrients availability of rendered animal proteins. Following the same pattern, addition of 88 exogenous enzymes to the batch cooker, associated with low-temperature and low-pressure 89 processing, has been one of the alternatives used to mitigate effects of overheating the feather 90 meal, improving the quality of the end product and saving energy (Pedersen et al. 2012). 
The present investigation was performed to validate the suitability of different grades and

92 processing of PMM as a replacement for fishmeal in diets for gilthead sea bream juveniles. We

93 aimed to confirm their effects on growth performance feed utilization efficiency and changes in

94 muscle fillet lipid composition. Additionally, information about chemical composition and

95 nutritional values of specialized blood protein and feather meals as supplements in diets for such

96 species are required for feed manufacturers. Therefore, evaluation of category III premium

97 processed animal proteins (PAP's) is a necessary step towards their potential re-introduction

98 into the Aquafeed sector in Europe. More economic production of such high value marine fish

99 species such as gilthead sea bream based on a range of alternative feed ingredients and animal

100 by-products are destined to be at the forefront of these objectives.

101 It was also of interest to examine a blend of soya bean meal with PMM as a strategy to evaluate

102 any complimentary benefits of such combinations in complex formulations with lower fishmeal

103 inclusions typical in modern day formulations for marine fish species. These diets were

104 formulated under the advice of the collaborating company to extend the use of PAPS in marine

105 fish diets. It was not the aim to correct for any specific amino acid deficiencies such as

106 methionine but to test the maximum feasible inclusion of PMM. Enzyme treated feather meal

107 (EFM) and also a spray-dried hemoglobin meal (SDHM) were included as supplements to

108 evaluate their nutritional enhancement potential in terms of their protein contribution to partially

109 reduce the fish meal content of seabream diets. Additionally, the opportunity to record the fatty

110 acid composition of sea bream fed a fish meal control diet with fish oil against higher

111 substitution of Poultry Meat Meal was undertaken to assess the extent of changes in the major

112 Omega-3 (n-3) HUFA's such as EPA and DHA (eicosapentaenoic and docosahexaenoic acids

113 respectively). This is because of the high fat content in PMM and a consequent reduction in fish 
114 oil to accommodate a consistent diet lipid content. A de-fatted PMM was also tested to allow

115 fish oil in the formulation to maintain the optimum level of total $n-3$ in the diets. This is

116 important from the retail and consumer perspective and is of topical interest.

\section{Materials and methods}

118 Generic fish and experimental conditions

119 The first feeding trial was conducted in a closed re-circulating seawater system conforming 120 to a Recirculating aquaculture system (RAS) design for specific nutrition research. The 121 experimental facility consisted of sixteen 110-L volume fibreglass (square) tanks connected to a 122 biological and mechanical filtration unit (sponge filters, protein skimmer and submerged 123 biological filter beds). Each tank was supplied with filtered seawater (salinity: $33 \pm 1$ ppt; 124 temperature: $22 \pm 1{ }^{\circ} \mathrm{C}$ ) at a rate of $10 \mathrm{~L} \mathrm{~min}^{-1}$ and continuously aerated so that oxygen levels 125 were kept close to saturation. Besides, natural seawater was used to renew $\sim 20 \%$ of the water 126 system volume every week. Throughout the study, monitoring of the principal water quality 127 parameters resulted in average values of: 7.5 for $\mathrm{pH}$ (Hanna $\mathrm{pH} 210$ benchtop meter), $0.15 \mathrm{mg} \mathrm{L}^{-}$

$128{ }^{1}$ for total ammonia nitrogen (Hanna chemical test kits) and $91.5 \%$ saturation for DO (YSI 129 model 85 portable meter). Photoperiod followed a cycle of $12 \mathrm{~h}$ dark, $12 \mathrm{~h}$ light. Fish husbandry 130 and experiments conformed to the local institutional Animal Welfare Ethics Committee Codes 131 of Practice and were in accordance with the UK Animal Scientific Procedures Act, 1986. At the 132 beginning of the experiment, a pooled sample of fish (25 seabream) was taken for determining 133 chemical body composition (initial carcass sample). At the end of the experiment, 3 fish were 134 sampled from each tank, 9 per treatment in total. Fish were killed with an excess concentration 135 of anesthetic (MS 222, Tricaine methanesulfonate) and then individually weighed. The fish 
136 were then pooled per tank (final carcass sample) for chemical analyses. The combined fish

137 samples were ground in a coffee grinder and stored at $-20{ }^{\circ} \mathrm{C}$ until analyzed.

138 Trial 1

139 Fish stock and feed management

140 The juvenile gilthead sea bream (Sparus aurata L.) used in Trial 1 were obtained from a

141 commercial hatchery in France (Aquastream, Ploemeur) and acclimatized to the environmental

142 conditions for a period of 4 weeks prior to trial commencement. During that period, they were

143 fed a commercial marine fish diet (Skretting Salmon Nutra) twice daily to apparent satiation. At

144 the start of the trial, fish were group weighed (initial individual weight: $22.7 \pm 0.5 \mathrm{~g}$, mean \pm

$145 \mathrm{SD}$ ) and re-stocked at a density of 25 fish per tank. Fish were hand fed to $3 \%$ body weight per

146 day twice daily. Following the one day of feed deprivation each week, the fish were weighed,

147 and the feeding rate recalculated to correct for biomass changes and maintain accurate feeding 148 level.

149 Diet preparation and experimental design

150 For this investigation, FM (LT94) was provided by Skretting Ltd, Longridge, Preston, 151 Lancashire, UK and the protein sources used in this trial were obtained from Prosper De Mülder 152 Group, Market Harborough, UK (PMM) (Now Saria Group GmbH) and from Skretting Ltd, 153 Longridge, Preston, Lancashire, UK (Hi-Pro soybean meal, SBM). The processing method and 154 origin of poultry derived-proteins included in the four experimental diets was as follows: the 155 poultry meat meal (PMM) grade is derived from mixed species poultry material (i.e. chickens, 156 turkeys, ducks and geese slaughtered fit for human consumption) minced to $<3 \mathrm{~mm}$ and 157 introduced into a continuous process (Rotadisc) in the presence of natural fats to evaporate the 158 water, and subsequently sterilized (residence time: $90 \mathrm{~min}$, maximum temperature: $125^{\circ} \mathrm{C}$ ). The 
159 resulting material is concentrated by an expeller press to remove fat. The protein rich fraction is

160 subsequently cooled and milled. From this product, the enzyme treated feather meal (EFM) was

161 provided by Prosper de Mülder Group (now Saria Group GmbH), Market Harborough, U.K. Mixed

162 feathers are heated to $50{ }^{\circ} \mathrm{C}$ for $30 \mathrm{~min}$ in the presence of a commercial enzyme additive of fungal

163 source $\left(\right.$ Synergen ${ }^{\mathrm{TM}}$, Alltech Biotechnology) containing amylase, cellulose, phytase, xylanase, $\beta$ -

164 glucanase, pectinase and an active protease, 12,700 HUT $\mathrm{g}^{-1}$ (E.C.3.4.23.18). This enzyme

165 hydrolysis step (keratinolysis), likely results in the cuticle layer being partially degraded and smaller

166 peptides produced, however there appears to be no effect on di-sulphide bonds in Keratin per se

167 according to Considine (2000) although the concentration of cysteine increases in the enzyme

168 treated product. The treated feathers are subsequently processed at $200 \mathrm{kpa}$ for $15 \mathrm{~min}$ at a

169 temperature of $125^{\circ} \mathrm{C}$. The resulting ground meal is dried in a Rota-disc drier to $5 \%$ moisture and

170 ground to an average particle size of 300 microns $(\mu)$.

171 The spray-dried haemoglobin meal (SDHM; Spray-dried porcine animal blood cells-AP301 ${ }^{\circledR}$ ) was

172 supplied by APC Inc. Europe S.A., Barcelona, Spain. The specifications of the different test

173 ingredients utilized in both trials are given in Table 1. A FM based diet served as the control dietary

174 formulation (Table 2). Using pre-established digestibility coefficients (Davies Gouveia, Laporte,

175 Woodgate \& Nates 2009), five experimental diets (PMM25, PMM50, PMM75, SDHM10 and

176 EFM5) were derived from the basal formulation to achieve specific replacement of the protein

177 component of FM replacement levels with various animal by-products (25, 50 and $75 \%)$ for PMM;

$1785 \%$ for EFM and $10 \%$ for SDHM while maintaining digestible protein and lipid levels constant at

$17940 \%$ and $15 \%$ respectively across all dietary treatments in compliance with the nutritional

180 requirements for gilthead sea bream NRC (2011). During feed preparation, all macro-ingredients,

181 vitamins and minerals premixes were uniformly mixed together before the addition of marine fish oil 
182 and de-ionised water. The resulting mixture was extruded through a $3 \mathrm{~mm}$ aperture die of a California

183 pellet mill. Pellets were air-dried by convection in a warm air cabinet $\left(37^{\circ} \mathrm{C}\right)$ and stored in plastic

184 sealed containers throughout the duration of the study. Each diet was fed to 3 replicate groups of fish

185 for a period of 9 weeks.

$186 \quad$ Trial 2

187 Fish stock and feed management

188 The juvenile gilthead sea bream (Sparus aurata L.) used in Trial 2 were obtained from a 189 commercial hatchery in France (Aquastream, Ploemeur) and acclimatized to the environmental 190 conditions for 4 weeks before the start of the experiment. During that period, they were fed a 191 propriety commercial marine fish diet (Skretting Salmon Nutra) as in trial 1. At the start of the 192 trial fish were group weighed (initial individual weigh: $10.07 \pm 0.05 \mathrm{~g}$, mean $\pm \mathrm{SD}$ ) and re193 stocked at a density of 50 fish per tank. Fish were hand fed to $4 \%$ body weight per day twice 194 daily and corrected at each weekly weighing as described in trial 1.

195 In Trial 2, five semi-purified diets were designed to attain a target of $400 \mathrm{gkg}^{-1}$ digestible 196 protein, $150 \mathrm{gkg}^{-1}$ lipids and formulated to meet current known nutritional requirements for 197 gilthead sea bream juveniles (Table 3). For the 4 experimental diets, the FM in the control diet 198 was partially replaced by the following ingredients: PMM (75\% FM substitution level), a 199 defatted grade of the same PMM (50 and 75\% FM substitution level) and a 50:50 mixture of 200 defatted PMM (dPPM) provided by Prosper de Mülder Group, Market Harborough, UK and 201 SBM (Hi-Pro SBM; 50\% FM replacement level) provided by Skretting Ltd, Longridge, Preston, 202 Lancashire, UK. In this study, a further defatting of the material was achieved. Deffated PMM 203 (dPMM) was obtained following hexane extraction: PMM was soaked and mixed for $24 \mathrm{~h}$ and 204 filtered through a $100 \mu$ sieve to remove the fat and solvent mixture; the defatted sample was 
205 then air dried to remove traces of solvent. Each diet was fed to 3 replicate groups of fish for a 206 period of 6 weeks.

207 Water quality

208 The water temperature was maintained at $25 \pm 1{ }^{0} \mathrm{C}$ for the sea bream for best growth) with a 209 salinity of 33-34 ppt. The photoperiod was maintained at12-h light: 12-h dark by means of

210 artificial daylight simulation. All fish were held in $65 \mathrm{~L}$ fiberglass tanks $(40 \mathrm{~cm}$ length, $17.5 \mathrm{~cm}$

211 width and $27-38 \mathrm{~cm}$ depth) on the basis of the Guelph model (tanks were made with a sloping

212 floor so that faecal material could be voided and recovered in external conical transparent

213 separation chambers fitted with a valve). Within the system, the flow rates applied enabled a

214 complete exchange of three to five volumes per hour. All principal water quality parameters

215 were controlled on a regular basis during the course of the study to remain within satisfactory 216 limits.

\section{Analytical methods of feeds and body composition}

218 Proximate analysis of ingredients, experimental diets and fish conformed to standard AOAC 219 methods (AOAC 2003). Essential amino acids were determined by Eclipse Scientific Group 220 (Chatteris, Cambrideshire, England) using standard protocols. Samples were first digested using $2216 \mathrm{~N} \mathrm{HCl}$ and tryptophan treated separately with $4 \mathrm{~N}$ Methane sulphonic acid. Digested samples 222 were subsequently diluted with HPLC grade water. All samples were subjected to pre-column 223 derivatisation with o-Phthaldialdehyde OPA with gradient HPLC using a Nucleosil C18 5 um, $22460 \times 4 \mathrm{~mm}$, Knauer column at ambient temperature with subsequent fluorescence detection at 225 330-365 $\mathrm{nm}$ excitations and 440-530 nm emission. A gradient elusion was employed with the 226 mobile phase being; A, $0.1 \mathrm{M}$ sodium acetate, $\mathrm{pH} 6.95$ and methanol: tetrahydrofuran (92.5: 5: 227 2.5) and $\mathrm{B}$, methanol: tetrahydrofuran (97.5: 2.5) with a flow rate of $1.2 \mathrm{ml} \mathrm{min}^{-1}$. In Trial 2, the 
228 fatty acid profile of the experimental diets was determined (FM, PMM75, dPMM75) along with

229 the corresponding final carcass samples by Eclipse Scientific group; Cambridgeshire; UK;

230 (Table 4) following FAME preparation and subsequent GLC separation and quantification with

231 standard FAME fatty acids (Table 7). Table 1 shows the nutritional composition including the

232 essential amino acid profiles of the test ingredient sources. Both tables 2 and 3 present the diet

233 formulations, their nutritional analysis and also essential amino acid profiles for trials 1 and 2

234 respectively.

\section{Statistical treatments}

236 Statistical analysis of data was performed using one-way analysis of variance (ANOVA) at 237 the 5\% level of significance. Tukey's post hoc analysis was applied to mean values where 238 appropriate (Minitab 13 for windows, Minitab Inc., State College, USA).

239 Results

$240 \quad$ Trial 1

241 Growth performance and feed utilisation

242 Growth performance and feed utilization for gilthead sea bream fed the experimental diets 243 are presented in Table 4. Fish showed on average a 200\% increase in weight gain with all 244 treatments producing specific growth rates (SGR's) comparable to the control diet, there were 245 no significant differences $(\mathrm{P}=0.71)$ in SGR between $(\mathrm{FM})$ diet $1.7 \%$ day $^{-1}$ and the highest 246 PMM level of $75 \%$ dietary protein replacement $\left(1.6 \%\right.$ day $\left.^{-1}\right)$, however a significant $(P<0.05)$

247 reduction of feed intake with increasing PMM substitution apparent at the highest level $(0.9 \mathrm{~g}$ 248 fish $^{-1}$ day $\left.^{-1}\right)$ compared to $\left(1.0 \mathrm{~g} \mathrm{fish}^{-1}\right.$ day $\left.^{-1}\right)$ for the FM fed group.

249 However, a significant $(P<0.05)$ decrease of feed conversion ratios $(\mathrm{FCR})$ values were 250 obtained for SDHM10, EFM5 and PMM25 groups (1.30-1.37), also, fish fed higher inclusion 
251 level of PMM showed improving in FCR (1.37) compared to the FM group (1.43) consistent 252 with the other parameters but not deemed significant $(P<0.05)$.

253 A weight gain (g) and weight gain (\%) of gilthead sea bream fed the SDHM10 and PMM25

254 diets were apparently more efficient $(\mathrm{P} \geq 0.05)$ than fish fed $F M$, following the same pattern 255 converting dietary protein to live weight gain (protein efficiency ratio (PER) were 1.62 and 1.60

256 vs. 1.5 for fish fed SDHM10 and PMM25 diets vs. fish fed FM (Table 4). On the other hand, the 257 PER of fish fed PMM75 was significantly $(P<0.05)$ lower $(1.4)$ compared to all other 258 experimental groups (1.5-1.6, Table 6). However, there were not reflected by the direct 259 calibration of apparent net protein utilization (aNPU) for a group of fish which ranged from

$26021.4 \%$ to $23.6 \%$. No statistical differences $(P>0.05)$ were found in the proximate composition of 261 whole fish carcass (Table 4). Considering the pattern of protein retention relative to the amount 262 of protein fed, aNPU observed across treatments were found not to be statistically different $263(P>0.05)$.

264 Health related parameters

265 Following the 9-week period in trial 1, the different diets tested did not significantly $266(P>0.05)$ influence the condition factor $(\mathrm{K})$ or hepato-somatic index (HSI) of the fish. No 267 significant $(P>0.05)$ differences were found in the hematocrit value, haemoglobin concentration 268 or Red Blood cell count (RBCC) among the blood samples analysed. Values ranged from 36.5 269 to 42.0 (Hct, \%), 7.2 to $7.8\left(\mathrm{Hb}, \mathrm{g} \mathrm{dL}^{-1}\right), 2.2$ to $2.7\left(\mathrm{RBCC} 10^{6} \mathrm{~mm}^{-3}\right)$ respectively within the test 270 groups, against $39.00(\mathrm{Hct}, \%), 7.7\left(\mathrm{Hb}, \mathrm{g} \mathrm{dL}^{-1}\right)$ and $2.4\left(\mathrm{RBCC} 10^{6} \mathrm{~mm}^{-3}\right)$ for the control diet 271 (Table 5).

$272 \quad$ Trial 2

273 Growth performance and feed utilisation 
After 42 days of feeding, significant $(P<0.05)$ differences were found in live weight gain and 275 SGR of gilthead sea bream juveniles receiving PMM and defatted PMM (dPMM; Table 6). Fish 276 fed with the control diet had a mean weight gain that was significantly $(P<0.05)$ higher than 277 those fed with PMM75 and dPMM75. The same pattern was observed with SGR (FM: 3.6\% / 278 day; dPMM50: 3.5\% / day; SBM/dPMM: 3.4\% / day; PMM75: $3.2 \%$ / day and dPMM75: 3.2\% / 279 day).

280 Feed conversion ratios were significantly $(P<0.05)$ improved for diets including the 281 alternative protein sources in comparison with the control diet. A similar trend was observed for 282 PER: fish fed the blend of SBM/dPMM and dPMM75 were more efficient at converting protein 283 into live weight gain with PERs of 1.5 and 1.3 respectively. Likewise, superior aNPU values 284 were obtained form the PMM75 and dPMM75 levels with the PMM75 (aNPU 25.4\%) 285 significantly $(P<0.05)$ better than the FM fed gilthead sea bream $(21.6 \%)$. The SBM/dPMM 286 blend also resulted in a significantly $(P<0.05)$ higher aNPU $(27.76 \%)$ compared to the dPMM50 287 and FM groups (22.7\% and 21.6\% respectively). The PER from gilthead sea bream fed the 288 blend of dPMM75 and SBM/dPMM was significantly $(P<0.05)$ higher $(1.3$ and 1.5$)$ 289 respectively compared to the FM group (1.1).

290 No major significant differences $(P>0.05)$ were observed in gross nutrient composition of 291 fish carcasses analyzed at the end of this trial (Table 6). The FA analysis of the PMM diets 292 demonstrated the expected trend associated with diet lipid composition (i.e. lipid sources; Table 293 7). In the control diet, where lipid was primarily of marine origin, the ratio of n-3/n-6 fatty acids 294 was highest (2.53). In PMM75, where poultry fat accounted for $\sim 50 \%$ of the total lipid content, 295 this ratio decreased to 0.41 . This was largely a consequence of a reduction in 20:5n-3 (from $2961.4 \%$ to $0.8 \%$ ) and $22: 6 \mathrm{n}-3$ (from $1.9 \%$ to $0.9 \%$ ) as well as an augmentation of $18: 2 \mathrm{n}-6$ (from 
$1 \%$ to $6.7 \%$ ). The amount of animal fat present in PMM 75 diet was also reflected by an

298 increase in 16:0 and 18:1n-9 when compared to the control diet. Finally, the utilization of a

299 defatted source of PMM in dPMM75 allowed restoration of the n-3/n-6 FA's ratio at 1.14 . For

300 this diet, compared to the one where $75 \%$ of FM was replaced with full fat PMM, the amount of

$30118: 1 n-9$ decreased from $32.9 \%$ to $24.3 \%$ while the level of $18: 2 n-6$ varied from $6.7 \%$ to $4.4 \%$ in

302 the tissues of gilthead sea bream.

303 Discussion

304 This evaluation of a premium grade PMM and refined blood and feather meal proteins in 305 diets for gilthead sea bream follows the previous foundation studies of Davies et al. (2009).

306 Consequently, the trials acted as a prerequisite for more accurate substitution of processed 307 animal proteins (PAP's) into balanced diet formulations for this species in contemporary aqua 308 feeds. On this basis, the substitution of FM with PMM and EFM as well as SDHM was effective 309 due to prior knowledge of the protein and energy digestibility data compared to the other 310 previous studies using gross nutrient levels.

311 Trial 1 validates the efficacy of using up to $75 \%$ of the dietary protein as PMM (57\% of diet)

312 with performance of juvenile gilthead sea bream attaining the same criteria measured as those

313 fed a control diet. There was only a slight indication of a reduced palatability encountered at this

314 level for this ingredient, with seabream adapting to its inclusion. Growth and feed utilization

315 indicators supported the use of PMM and strategic use of EFM and SDHM as reported for this

316 fish species (Serwata 2007; Yones \& Metwalli 2016; El-Husseiny et al. 2018). The overall EAA

317 profile of the PMM75 diet was similar to a high-quality FM protein control. In our

318 investigation, we replaced LT FM with the test ingredient at commercially acceptable levels and

319 found that a majority of EAA's exceeded requirement levels as expressed as percent of protein 
320 for all diets, except for $75 \%$ inclusion of PMM where both methionine and histidine was below

321 the reported requirement for sea bream by Peres \& Olivia-Teles (2009). It should be noted that

322 these workers used a mixture of whole protein and crystalline amino acids in semi-purified diets

323 for sea bream. Given the inefficiency of crystalline amino acids utilization in some species this

324 could elevate the apparent requirements of essential amino acids and is not strictly comparable

325 with the present study with whole protein sources. A better comparison arises from the data

326 found for sea bream and related species in the NRC 2011 Nutrient Requirements of Fish and

327 Shrimp.

328 The trend in decreasing SGR for gilthead sea bream, although deemed not significant, may

329 have reflected these shortages of EAA's. Thus, specific deficiencies of these amino acids may

330 have caused reduction in growth performance; furthermore, the lower growth performance

331 observed in gilthead seabream may be due to a slightly reduced palatability of the PMM

332 compared to fishmeal. The other factor that could be the major reason for declining the growth

333 may be due to the varying quality of tested PMM, which are significantly influenced by their

334 processing methods (Shapawi, Ng \& Mostafa 2007; Rostamian et al. 2016). It was interesting

335 that diets only supplemented with either a SDHM and and EFM showed as good a performance

336 as the FM group and superior to the higher levels of PMM inclusion (50 and 75\%). These diets

337 complied with the amino acid pattern of the fish meal diet meeting all EAA requirements for

338 this species. These results could be explained due to the use of the commercial enzyme

339 Synergen $^{\mathrm{TM}}$ that can help to enhance the degradation of the keratin structure in feather meal to

340 small peptides and increase the overall cysteine amino acid concentration in the feather meal;

341 however we based our EFM inclusion on a previous protein digestibility coefficient of $25 \%$ for

342 gilthead sea bream (Davies et al. 2009) although individual EAA digestibility may be higher for 
343 this species. In the latter study, higher inclusions of feather meal were used for digestibility 344 determination and this may have explained the much-reduced DC for this ingredient. Only 5\% 345 feather meal was included in the current investigation and may not be strictly comparable to the 346 conditions of the study by Davies et al 2009.

347 The FCR and PER values were significantly improved indicating enhanced nutritional value 348 of SDHM10. Indeed, combinations of animal proteins may show complementary amino acid 349 profiles. Such synergistic characteristics of complementary proteins need to be examined for 350 further FM replacement by exploring various protein blends. For example, the histidine level in 351 SDHM is appreciably higher than those found in FM and PMM. Although isoleucine 352 concentration is lower in SDHM, it is nonetheless a valuable source of leucine (12\% of total 353 protein) which is an EAA for gilthead sea bream (4.5\% of dietary protein).

354 In Trial 2, the control diet produced the overall best growth performance of juvenile gilthead 355 sea bream compared to other treatments containing poultry meat meals (PMM's) although the 356 defatted PMM and blended PMM with SBM produced favorable results although not deemed to 357 be significantly different to FM alone. However, improved protein utilization efficiency was 358 also seen in terms of the aNPU reported for gilthead sea bream fed PMM and dPMM at $75 \%$ 359 total protein replacement. These values are in accordance with data reported for this species by 360 Nengas Alexis \& Davies (1999) and Laporte (2007). Consequently, fish fed the SBM/dPMM 361 blend as a partial FM replacement grew as well as the fish fed the FM and exhibited the best 362 productivity values in terms of FCR, PER and aNPU. Although both protein sources are said to 363 be deficient in methionine (Nengas et al. 1999; Hertrampf \& Piedad-Pascual 2000), combining 364 SBM and PMM might result in a partial improvement of the EAA compared to the use of SBM 365 alone as soybean meal is a major plant ingredient in marine fish diets within low fishmeal 
366 formulations. This blend may mitigate the effects of the lower methionine, arginine and lysine

367 content in SBM in gilthead sea bream diets. This result tends to confirm an optimal substitution

368 rate of FM by $\mathrm{PMM}$ between 25 and $50 \%$ for this particular marine species. For most

369 carnivorous fish, the recommended substitution rates of FM by PBM (studies with sub adult fish

370 mainly) would generally range from 25 to 50\% (Nengas et al. 1999; Turker, Yigit, Ergün,

371 Karaali \& Erteken 2005; Yigit, Erdem, Koshio, Ergün,Türker \& Karaali 2006; Wang, Han,

372 Zheng \& Bureau 2008; Yu 2008; Li, Wang, Zheng, Jiang \& Xie 2009; Booth, Allan \&

373 Anderson 2011; Metts, Rawles, Brady, Thompson, Gannam, Twibell \& Webster 2011;

374 Moutinho et al. 2017) but the feasibility of even higher or total replacement without amino acid

375 supplementation was reported by some authors (Takagi, Hosokawa, Shimeno \& Ukawa 2000;

376 Saadiah, Abol-Munafi \& Utama 2011). Removing the poultry fat component of PMM to test a

377 75\% FM replacement with a relatively "pure" protein source did not yield any improvement

378 compared with the same inclusion level of the original full fat PMM (indicating the minimal

379 influence of dietary lipid on production performance). PMM75 and dPMM75 diets appeared to

380 be equally palatable to the fish since exactly the same amount of feed were consumed (FI $=0.98$

$381 \mathrm{~g} \mathrm{fish}^{-1}$ day $^{-1}$ ). By comparison with dPMM50, the SBM/dPMM blend did not lead to a

382 significant reduction of feed intake in sea bream. While the efficacy of SBM to replace FM in

383 diets for gilthead sea bream was also examined by several researchers (El-Haroun \& Bureau.

384 2007), limited information is available on the use of blends of SBM and animal protein

385 concentrates in this species (De Francesco, Parisi, Pérez-Sánchez, Gómez-Réqueni, Médale,

386 Kaushik, Mecatti \& Poli 2007; Dias et al. 2009). Palatability and EFA profile of PMM are

387 presumed to be the main factors limiting the growth of gilthead sea bream, when full fat grades

388 of PMM are included at a high level, as seen in trial 1. The blending of SBM with dPMM 
appeared to raise the amino acid levels towards those observed in the dPMM50 diet and only

390 methionine seemed to remain below the reported requirement levels for sea bream by Peres \&

391 Olivia-Teles (2009). Separate short-term and long-term palatability trials are to be encouraged

392 to test limitation on feed intake for gilthead sea bream before practical use of such ingredients

393 can be applied in feed manufacture. Carcass FA profiles of gilthead sea bream conformed to the

394 expected changes in relation to the dietary FA patterns, with the 18:1n-9 (oleic) representative

395 of the poultry lipid signature becoming apparent. Agreeing with what is usually described in

396 wild or farmed gilthead sea bream (Mnari, Bouhlel, Chraief, Hammami, Romdhane, El Cafsi \&

397 Chaouch 2007), 16:0, 18:1n-9 were the principal saturated fatty acid (SFA) and mono

398 unsaturated fatty acid (MUFA) regardless the dietary regime. 22:6n-3 (was the dominant highly

399 unsaturated fatty acids (HUFA) within the carcass of fish fed FM and defatted (dPMM75),

400 whereas 18:2n-6 appeared to be the primary HUFA in the carcass of fish fed PMM75. Marine

401 fish are usually not known to have the ability to elongate and desaturate C18n-3 HPUFA

402 (linolenic) to effectively generate the long chain C20:5n-3 and C22:6n-3 (eicosapentaenoic and

403 docosahexaenoic) FA's respectively (Greene 1990). Within the context of total FO replacement,

404 the lack of a well-balanced FA profile (Sargent, Henderson \& Tocher 2002) and a lower

405 palatability (Regost, Arzel, Robin, Rosenlund \& Kaushik 2003) or digestibility (Caballero,

406 Obach, Rosenlund, Montero, Gisvol, Izquierdo 2002) are likely to limit the success of marine

407 fish production when other lipid sources are utilized at the expense of fish oils. In this study, sea

408 bream requirements for EFA's were likely met since diet manipulation did not result in a

409 reduction of FO below $50 \%$ of the total dietary lipid content for this species, and a total n-3 in

410 the diet of $3.1 \%$ of the oil $(0.4 \%$ of the diet) was retained in a PMM level of $75 \%$ inclusion

411 (trial II). The minimum requirement for the Gilthead sea bream was found to be $0.4 \%$ of the diet 
412 by Ibeas, Cejas, Fores, Badia, Gomez \& Hernández (1997) for EPA: DHA. No pathological

413 signs of essential fatty acid deficiencies such as skin hemorrhaging or fin erosion were observed

414 in our study and fish were in excellent condition throughout.

415 It is well established from the literature that the nature of dietary oil influences carcass 416 quality and FA pattern in fish tissues and organs for the gilthead sea bream (Izquierdo, Montero, 417 Robaina, Caballero, Rosenlund \& Ginés 2005; Caballero, Torstensen, Robaina, Montero \& 418 Izquierdo 2006; De Francesco et al. 2007; Piedad-Pascual et al. 2007). However, Aoki 419 Shimazu, Kukushige, Akano, Yamagata \& Watanabe (1996); Wang et al. (2008); Li et al. 420 (2009); Booth et al. (2011) did not find any noticeable difference in the flesh quality between 421 adult red sea bream (Pagrus major), Malabar grouper (Epinephelus malabaricus) and Australian 422 snapper (Pagrus auratus, Sparidae) respectively fed with or without FM as a dietary protein 423 source. In terms of human consumption and consumer acceptance high levels of HUFA in fish 424 muscle that can be obtained with proper diet manipulation would be a desirable benefit (Kaushik 425 1997; Trushenski \& Boesenberg 2009). The varying ratios of n-3 to n-6 and n-9 ratios resulting 426 from the dietary changes within the current study may have such implications for gilthead sea 427 bream; especially if the fish are fed diets containing a standard PMM over a longer time course and 428 particularly gilthead sea bream attaining harvestable weight. It may also be possible to enhance 429 marine fish diets containing poultry meat meals with selected algal products like Schizochytrium sp 430 containing high levels of DHA (docosahexaenoic acid) constituting the bulk of their n-3 fatty acids 431 and around $25 \%$ of the dry biomass. This could be provided during the final phase of production in a 432 'finisher' diet. The algal meal and extracted oil would complement such diets for sea bream and sea 433 bass allowing for optimization of the $n-3$ profile in the flesh of fish for the consumer. This concept 
434 has been explored for Atlantic salmon (Salmo salar) by Kousoulaki, Nengas Sweetman \& Berge 435 (2016) with promising results.

436 Future processing of PMM to remove residual fat could be employed at the finishing phase of 437 production to mitigate the changing of $n-3$ to $n-6 \& n-9$ ratios in compliance to consumer demands 438 for a defined product with high omega-3 highly un-saturated fatty acid (HUFA) lipids notably EPA 439 and DHA. The trend towards a reduced $n-3 / n-6$ ratio in the fillets of farmed salmon has been well 440 documented recently with much concern that the combined EPA and DHA levels have been 441 reduced by as much as $50 \%$ over the last 15 years mainly due to the increased utilization of 442 vegetable oils like Canola and soybean oils in salmonid feeds (Sprague, Dick \& Tocher 2016). 443 Indeed, we see this potential here with sea bream, if diets with higher animal fat levels are 444 constructed. Evidence for correction by using defatted PMM is shown in our study to allow more 445 formulation space for alternative oil sources richer in both EPA and DHA hence restoring the same 446 profile of fatty acids in the control fishmeal diet for seabream.

447 The present investigation confirms that PMM is an effective protein concentrate supporting 448 growth and development of juvenile gilthead sea bream replacing up to $75 \%$ of FM protein. 449 There may be additional benefits by the inclusion of supplementary levels of 5 and $10 \%$ 450 respectively of EFM and SDHM as premium grade ingredients to provide enhanced EAA 451 contribution and enhanced palatability of diets with reduced fishmeal levels. However, despite a 452 trend in the technical improvement of rendered animal by-products over the last two decades, 453 the threshold for maximizing dietary inclusion has not been realized compared to the earlier 454 findings of Nengas et al. (1996 \& 1999). The cost benefit analysis of further technological 455 processing must be re-assessed as well as more work to using supplementary crystalline amino 456 acid in conjunction with these protein sources. 
Clearly there is still much scope in developing feeds for gilthead sea bream and other marine

458 species based on a new generation of by-products, contributing towards a bio-secure and

459 sustainable agenda for the aquafeed sector within a European context and beyond. As a result of

460 this research, EU dependency on imported alternative protein sources for use in aquaculture

461 feeds such as soya bean meal could be adding a measured contribution to global food security

462 by reducing plant ingredient imports. The research has also contributed to the Common

463 Fisheries Policy of aligning sustainable wild fisheries with sustainable aquaculture development

464 by considering alternative strategies. The scientific evidence leading to regulatory change at the

465 EU level involved significant industry investment in research and development leading to

466 improved competitiveness of the EU aquaculture industry, a reduction in the environmental

467 impact of fish farming and improved fish health and welfare.

468 New scientific information concerning the safety and efficacy of inclusion of mono-PAPs in

469 farmed fish diets was established in the last decade. This has now led to regulatory change at the EU

470 level (Regulation introduced Feb 2013), permitting re-authorization of the use of mono-PAPs in

471 aquaculture diets. However, in the UK and some EU countries it is the retailer that restricts their use

472 due to the sensitivity of the consumer with regard to animal protein products in the food chain.

\section{Conclusion}

474 The results from this study showed that processed animal proteins have good nutritive value 475 and can be a valuable protein source for gilthead sea bream diets. Modest levels of these 476 ingredients can be used in gilthead sea bream feeds without detriment in a balanced formulation.

477 Novel techniques for producing processed animal protein and coupling with exogenous 478 enzymes associated with low-temperature and low-pressure processing, has been one of the 479 alternatives used to improving the quality of processed animal protein. Key opportunities may 
480 arise from the use of specific exogenous enzymes such as proteases and solid state fermentation

481 products to achieve superior digestibility of rendered animal material in aquafeeds. Also,

482 various ensiling methods to stabilize the protein component and fats could be applied as well as

483 natural ant-oxidants. The use of various feed additives such lactobacillus and probiotics with the

484 addition of organic carbohydrates is a relatively economic approach to achieve effective ensiling 485 and protein hydrolysis.

486 It is evident that further characterization of processed animal proteins (PAPS) and some 487 refinements of the diet formulation for seabream are required to obtain comparable levels of 488 performance with conventional higher fish meal-based diets for marine fish species. More work 489 will be needed to support the aqua-feed industry in addressing both the retailers and consumer 490 confidence for fish fed animal by-products in the UK and Europe although widely accepted in 491 other parts of the world. These must also enable production of marine fish without altering the 492 amount of invaluable HUFA lipids in the fillets of fish to ensure maintaining the healthy 493 benefits to the consumer.

\section{Acknowledgements}

495 This work was previously funded by Prosper de Mülder PDM Group, UK, now under the Saria $496 \mathrm{GmbH}$ group) as developmental work to assess the safety and validation of their products for 497 strategic aquaculture applications.

\section{References}

499 Abwao, J., Safina, M., Ondiba, R., Ogello, E. \& Obiero, K. (2017). Effect of replacing marine 500 protein with hydrolyzed feather meal on growth, apparent digestibility and body 501 composition of juvenile tilapias; Oreochromis mossambicus (peters, 1852). International 502 Journal of Fisheries and Aquatic Studies, 5 (6), 242-250 
Abarraa, S., Velasqueza, S., Guzmana, K., Felipea, J. \& Ragazaa, J. (2017). Replacement of fishmeal with processed meal from knife fish Chitalaornata in diets of juvenile Nile tilapia, Oreochromis niloticus. Aquaculture Reports, 5, 76-83

Alexis, M.N. (1997). Fish meal and fish oil replacers in Mediterranean marine fish diets. In: Tacon, A.G.J., Basurco, B. (Eds.), Feeding tomorrow's fish, Zaragoza: CIHEAM-IAMZ, Cahiers Options Méditerranéennes, Vol. 22, 183-204.

AOAC (2003). Official Methods of Analysis of AOAC International,17 ${ }^{\text {th }}$ In: Horwitz, H. (Ed.), Arlington, Virginia, USA.

Aoki, H., Shimazu, H., Kukushige, T., Akano, H., Yamagata, Y., \& Watanabe, T. (1996). Flesh quality in red sea bream fed with diet containing a combination of different protein sources as total substitution for fish meal. Bulletin of Fisheries Research Institute of Mie, $6,47-54$.

Bendiksen, E.Å., Johnsen, C.A., Olsen, H.J., \& Jobling, M. (2011). Sustainable aquafeeds: progress towards reduced reliance upon marine ingredients in diets for farmed Atlantic salmon (Salmo salar L.). Aquaculture, 314, 132-139.

Booth, M.A., Allan, G.L., \& Anderson, A.J. (2011). Influence of poultry meal, meat meal or soybean meal inclusion on weight gain and production characteristics of Australian snapper Pagrus auratus. Aquacult. Int. On-line. DOI: 10.1007/s10499-011-9445-9.

Bureau, D.P., Harris, A.M., Bevan, D.J., Simmons, L.A., Azevedo, P.A., \& Cho, C.Y. (2000). Feather meals and meat and bone meals from different origins as protein sources in rainbow trout (Oncorhynchus mykiss) diets. Aquaculture, 181, 281-291.

Caballero, M.J., Obach, A., Rosenlund, G., Montero, D., Gisvol, M., \& Izquierdo, M. S. (2002). Impact of different dietary lipid sources on growth, lipid digestibility, tissue fatty acid 
composition and histology of rainbow trout Oncorhynchus mykiss. Aquaculture, 214, 253271.

528 Caballero, M. J., Torstensen, B.E., Robaina, L., Montero, D., \& Izquierdo, M. (2006). Vegetable 529 oils affect the composition of lipoproteins in sea bream (Sparus aurata). Brit. J. Nutr., 96, $530 \quad 830-839$

531 Considine, M.J. (2000). New enzyme technologies for poultry by-products. Proc. Aust. Poult. Sci. Sym. Altech Biotechnology Centre, Sarney, Meath, Ireland, 163-165.

Davies, S. J., Gouveia, A, Laporte, J., Woodgate, S., \& Nates, S. (2009). Nutrient digestibility profile of premium (category III grade) animal protein by-products for temperate marine fish species (European sea bass, gilthead sea bream and turbot). Aquaculture Research, 40,

De Francesco, M., Parisi, G., Pérez-Sánchez, J., Gómez-Réqueni, P., Médale, F., Kaushik, S.J., Mecatti, M. \& Poli, B.M. (2007). Effect of high-level fish meal replacement by plant proteins in gilthead sea bream (Sparus aurata) on growth and body/fillet quality traits.

541 Dias, J., Conceição, L.E.C., Ribeiro, A.R., Borges, P., Valente, L.M.P. \& Dinis, M.T. (2009). Aquaculture Nutrition, 13, 361-372. Practical diet with low fish-derived protein is able to sustain growth performance in gilthead sea bream (Sparus aurata) during the grow-out phase. Aquaculture, 293, 255-262.

544 Drew, M.D., Borgeson, T.L., \& Thiessen, D.L. (2007). A review of processing of feed 545 ingredients to enhance diet digestibility in finfish. Animal Feed Science \& Technology, $546 \quad 138,118-136$. 
El-Haroun, E.R., Azevedo, P.A., \& Bureau, D.P. (2009). High dietary incorporation levels of rendered animal protein ingredients on performance of rainbow trout, Oncohrynchus mykiss (Walbaum, 1972). Aquaculture, 290, 269-274.

El-Haroun, E.R., \& Bureau, D.P. (2007). Comparison of the bioavailability of lysine in blood meals of various origins to that of L-lysine HCL for rainbow trout (Oncorhynchus mykiss). Aquaculture, 262, 402-409.

El-Husseiny, O.M., Hassan, M. I., El-Haroun, E.R. \& Suloma, A. (2018). Utilization of poultry by-product meal supplemented with L-lysine as fish meal replacer in the diet of African catfish, Clarias gariepinus (Burchell, 1822). Journal of applied aquaculture. DOI: $10.1080 / 10454438.2017 .1412844$

Gatlin III, D.M., Barrows, F.T., Brown, P., Dabrowski, K., Gaylord, T.G., Hardy, R.W., Herman, E., Hu, G., Krogdhal, Å., Nelson, R., Overturf, K., Rust, M., Sealey, W., Skonderg, D., Souza, E.J., Stone, D., Wilson, R. \& Wurtele, E. (2007). Expanding the utilization of sustainable plant products in aquafeeds: a review. Aquaculture Research, 38, $551-579$.

Greene, D.H. (1990). Lipid Metabolism in Fish. In: Stansby, M.E., (Ed.), Fish Oils in Nutrition, Van Nostrand Reinhold, Publishers, New York, 313 pp.

Hardy, R.W. (2010) Utilization of plant proteins in fish diets: effects of global demand and supplies of fishmeal. Aquacult. Res., 41, 770-776.

Hatlen, B., Jakobsen, J.-V., Crampton, V., Alm, M., Langmyhr, E., Espe, M., Waagbø, R. (2015). Growth, feed utilization and endocrine responses in Atlantic salmon (Salmo salar) fed diets added poultry by-product Meal and blood meal in combination with poultry oil. Aquacult. Nutr., 21, 714-725. 
Hertrampf, J.W., \& Piedad-Pascual, F. (2000). Handbook on Ingredients for Aquaculture Feeds. Kluwer Academic Publishers, London. 573 pp.

Ibeas, C., Cejas, J. R., Fores, R., Badia, P., Gomez, T., \& Hernández, A. L. (1997). Influence of eicosapentaenoic to docosahexaenoic acid ratio (EPADHA) of dietary lipids on growth and fatty acid composition of gilthead seabream (Sparus aurata) juveniles. Aquaculture, 150(1-2), 91102.

Izquierdo, M.S., Obach, A., Arantzamendi, L., Montero, D., Robaina, L., \& Rosenlund, G. (2003). Dietary lipid sources for seabream and seabass: growth performance, tissue composition and flesh quality. Aquacult. Nutr., 9, 397-407.

Izquierdo, M.S., Montero, D., Robaina, L., Caballero, M.J., Rosenlund, G. \& Ginés, R. (2005). Alterations in fillet fatty acid profile and flesh quality in gilthead seabream (Sparus aurata) fed vegetable oils for a long term period. Recovery of fatty acid profiles by fish oil feeding. Aquaculture, 250, 431-444.

Kaushik, S.J. (1997). Recent developments in the nutrition and feeding of marine finfish of interest to the Mediterranean. In: Nutrition and the improvement of the seabass and seabream production in the Mediterranean Region, INVE "ALIIA" Conference, Thessaloniki, Greece, 10 pp.

Kaushik, S.J. (1998). Whole body amino acid composition of European seabass (Dicentrarchus labrax), gilthead seabream (Sparus aurata) and turbot (Psetta maxima) with an estimation of their IAA requirement profiles. Aquatic Living Resources, 11, 355-358.

Kaushik, S.J. \& Seiliez, I. (2010) Protein and amino acid nutrition and metabolism in fish current knowledge and future needs. Aquaculture Research, 41, 322-332. 
Kousoulaki, K. I. Nengas J. Sweetman R.K. \& Berge (2016). Microalgae and organic minerals enhance lipid retention efficiency and fillet quality in Atlantic salmon (Salmo salar L.). Aquaculture, 451, 47-57

Kumar, S., Sándor Zs, J., Nagy, Z., Fazekas, G., Havasi, M., Sinha, A. \& De-Boeck (2016).

Potential of processed animal protein versus soybean meal to replace fish meal in practical diets for European catfish (Silurus glanis): growth response and liver gene expression. Aquaculture Nutrition, DOI: 10.1111/anu.12487

Laporte, J. (2007). Nutritional evaluation of animal by-products for the partial replacement of fishmeal in diets for gilthead seabream (Sparus aurata L.). Ph.D. Thesis, University of Plymouth, UK. pp 265.

Li, K., Wang, Y., Zheng, Z.X., Jiang, R.L. \& Xie, N.X. (2009). Replacing fish meal with rendered animal protein ingredients in diets for Malabar grouper, Epinephelus malabaricus, reared in net pens. J. of the World. Aquac. Sco., 40, 67-75.

Lupatsch, I., Kissil, G.H., Skalan, D. \& Pfeffer, E. (1997). Apparent digestibility coefficients of feed ingredients and their predictability in compound diets for gilthead seabream, Sparus aurata. Aquaculture Nutrition, 3, 81-89.

Martínez-Llorens, S., Vidal, T., Moñino A.V., Ader, M.J., Torres, M.O. \& Cerdá, M.J. (2008). Blood and haemoglobin meal as protein sources in diets for gilthead seabream (Sparus aurata): effects on growth, nutritive efficiency and fillet sensory differences. Aquacult. Res., 39, 1028-1037.

Martínez-Llorens, S., Moñino, A.V., Vidal, A.T., Salvador, V.J.M., Torres, M.P., Cerdá, M.J., (2007a). Soybean meal as a protein source in gilthead sea bream (Sparus aurata L.) diets: effects on growth and nutrient utilization. Aquacult. Res., 38, 82-90. 
Martínez-Llorens, S., Vidal, T.A., Moñino, A.V., Torres, M.P. \& Cerdá, M.J. (2007b). Effects of dietary soybean oil concentration on growth, nutrient utilization and muscle fatty acid composition of gilthead sea bream (Sparus aurata). Aquacult. Res. 38, 76-81.

Metts, L.S., Rawles, S.D., Brady, Y.J., Thompson, K.R., Gannam, A.L., Twibell, R.G. \& Webster, C.D. (2011). Amino acid availability from selected animal- and plant- derived feedstuffs for market-size sunshine bass (Morone chrysops x Morone saxatilis). Aquacult. Nutr., 17, 123-131.

Mnari, A., Bouhlel, I., Chraief, I. Hammami, M., Romdhane, M.S., El Cafsi, M. \& Chaouch, A. (2007). Fatty acids in muscle and liver of Tunisian wild and farmed gilthead sea bream, Sparus aurata. Food Chemistry, 100, 1393-1397.

Moutinho, S., Martínez-Llorens, S., Tomás-Vidal, A., Jover-Cerdá, M., Oliva-Teles, A., \& Peres, H. (2017). Meat and bone meal as partial replacement for fish meal in diets for gilthead seabream (Sparus aurata) juveniles: Growth, feed efficiency, amino acid utilization, and economic efficiency. Aquaculture, 468, 271-277.

Nengas, I., Alexis, M.N. \& Davies, S.J. (1996). Partial substitution of fishmeal with soybean meal products and derivatives in diets for gilthead seabream Sparus aurata (L.). Aquacult. Res., 27, 147-156.

Nengas, I., Alexis, M.N. \& Davies, S.J. (1999). High inclusion levels of poultry meals and related byproducts in diets for gilthead seabream Sparus aurata L. Aquaculture, 179, 1323.

Novriadi, R., Spangler, E., Rhodes, M., Hanson, T., \& Davis, D. A. (2017). Effect of varions levels of squid hydrolysate and squid meal supplémentassions with enzyme-treated soy on 
growth performance, body composition, serum biochemistry and histology of Florida pompano Trachinotus carolinus. Aquaculture, 481, 85-93.

639

NRC (2011). Nutrient Requirements of Fish and Shrimp. Animal Nutrition Series. National Research Council of the National Academies. The National Academies Press. pp 376.

Oliva-Teles, A. (2000) Recent advances in European sea bass and gilthead sea bream nutrition. Aquacult. Int., 8, 477-492.

Peres, H., and Aires Oliva-Teles (2009). The optimum dietary essential amino acid profile for gilthead seabream (Sparus aurata) Juveniles Aquaculture, 296, 81-86.

Piedad-Pascual, M.A., Mazón, M.J., García García, B. \& Hernández, M.D. (2007). Effects of total replacement of fish oil by vegetable oils in the diets of sharp snout seabream (Diplodus puntazzo). Aquaculture, 263, 211-219.

Rawles, S.D., Gaylord, T.G., McEntire, M.E. \& Freeman, D.W. (2009). Evaluation of poultry by-product meal in commercial diets for hybrid striped bass Morone chrysops $\circ$ x $M$.

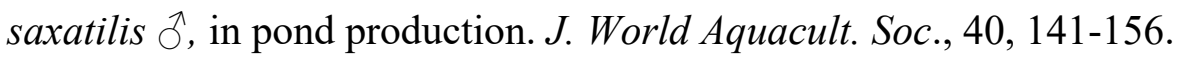

Rawles, S.D., Riche, M., Gaylord, T.G., Webb, J., Freeman, D.W. \& Davis, M. (2006). Evaluation of poultry by-product meal in commercial diets for hybrid striped bass (Morone chrysops female x M. saxatilis male) in recirculated tank production. Aquaculture, 259, 377-389.

Rawles, S.D., Thompson, K.R., Brady, Y.J., Metts, L.S., Aksoy, M.Y., Gannam, A.L., Twibell, R.G., Ostrand, S. \& Wesbster, C.D. (2011). Effects of replacing fish meal with poultry byproduct meal and soybean meal and reduced protein level on the performance and immune status of pond-grown sunshine bass (Morone chrysops x M. saxatilis). Aquacult. Nutr., 17, 708-721. 
660 661

662 663

664

665

666

667

668

669

670

671

672

673

674

675

676

677

678

679

680

681 682

Rebafka, F.-P. \& Kulshrestha, A. (2009). Adding value to feather meal. International Aquafeeds, 12, 14-17.

Regost, C., Arzel, J., Robin, J., Rosenlund, G. \& Kaushik, S.J. (2003). Total replacement of fish oil by soybean oil linseed oil with a return to fish oil in Turbot (Psetta maxima). 1. Growth performance, flesh fatty acid profile and lipid metabolism. Aquaculture, 217, 465-482.

Rostamian, N., Eagderi, S., Masoudi, E., Salar, H. \& Asadian, N. (2016). Complete replacement of fish meal with poultry by-product in diet formulated for rainbow trout (Oncorhynchus mykiss). ABAH Bioflux, 8 (1), 34-38.

Saadiah, I., Abol-Munafi, A.M. \& Utama, C.M.C. (2011). Replacement of fishmeal in cobia (Rachycentron canadum) diets using poultry by-product meal. Aquacult. Int., 19, 637-648.

Sargent, J., Henderson, R.J. \& Tocher, D.R. (2002). The lipids. In: Halver, J.E., Hardy, R.W. (Eds.), Fish Nutrition, $3^{\text {rd }}$ edition, Academic Press, San Diego, pp. 181-257.

SECA (2010). Commission Staff Working Document accompanying the Communication from the European Parliament and the Council of the TSE Road map 2 384, 16pp.

Serwata, R. (2007). Nutritional evaluation of rendered animal by products and blendes as suitable partial alternatives for fish meal in diets for rainbow trout, Oncorhynchus mykiss. MPhil Thesis, University of Stirling, UK, pp. 151.

Shapawi R, Ng WK. \& Mostafa S. (2007). Replacement of fish meal with poultry by-product meal in diets formulated for the humpback grouper (Cromileptes altivelis). Aquaculture, 273, 118-389.

Sprague, M., Dick, J. R., \& Tocher, D. R. (2016). Impact of sustainable feeds on omega-3 longchain fatty acid levels in farmed Atlantic salmon, 2006-2015. Scientific reports, 6, 21892. 
683 Steffens, W. (1994). Replacing fish-meal with poultry by-product meal in diets for Rainbow 684 trout, Oncorhynchus mykiss. Aquaculture, 124, 27-34.

685 Tacon, A. G., Hasan, M. R., \& Subasinghe, R. P. (2006). Use of fishery resources as feed inputs 686 to aquaculture development: trends and policy implications. Food and Agriculture 687 Organization of the United Nations.

688 Tacon, A.G.J., \& Metian, M. (2008). Global overview on the use of fish meal and fish oil in 689 690 industrially compounded aquafeeds: Trends and future prospects. Aquaculture, 285, 146-

691 Takagi, S.T., Hosokawa, H., Shimeno, S.M., \& Ukawa, M. (2000). Utilization of poultry by692 product meal in a diet for red sea bream Pagrus major. Nippon Suisan Gakkai Shi., 66, 693 428-438.

694 Trushenski, J.T., Boesenberg, J., \& Kohler, C.C. (2009). Influence of grow-out feed fatty acid 695 composition on finishing success in Nile tilapia. North Amer. J. Aquac., 71, 242-251.

696 Trushenski, J.T., \& Boesenberg, J. (2009). Influence of dietary fish oil concentration and 697 finishing duration on beneficial fatty acid profile restoration in sunshine bass Morone

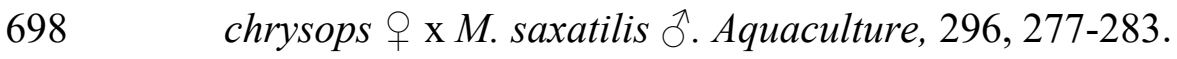

699 Turker, A, Yigit, M., Ergün, S., Karaali, B. \& Erteken, A. (2005). Potential of poultry by700 product meal as a substitute for fishmeal in diets for Black Sea turbot Scophthalmus 701 maeoticus: Growth and nutrient utilization in winter. Israeli J. Aquaculture-Bamidgeh, 57, 702 49-61.

703 Van der Velden, G. (2005). Blood meal, blood products \& gelatin-based binders in compound 704 aquafeeds. International Aquafeeds, 8, pp 12. 
705 Wang, J., Yun, B., Xue, M., Wu, X., Zheng, Y., \& Li, P. (2012). Apparent digestibility 706 coefficients of several protein sources, and replacement of fishmeal by porcine meal in 707 diets of Japanese seabass, Lateolabrax japonicus, are affected by dietary protein $708 \quad$ levels. Aquaculture Research, 43(1), 117-127.

709 Wang, Y., Han, K.L., Zheng, Z.-X. \& Bureau, D.P. (2008). Potential of using a blend of 710 rendered animal protein ingredients to replace fish meal in practical diets for Malabar 711 grouper (Epinephelus malabaricus). Aquaculture, 281, 113-117.

712 Wilson, R.P. (1994). Amino acid requirements of finfish. In: J.P.F.D, Mello (Ed.) Amino acids 713 in Farm Animal Nutrition. Cab International, pp. 377-399.

714 Woodgate, S.L. (2010). European Union Update. Paper presented at the Third Global Feed and 715 Food Congress, Cancun, Mexico. April 20-23 2010. 10 pp.

716 Yigit, M., Erdem, M., Koshio, S., Ergün, S., Türker, A., \& Karaali, B. (2006). Substituting fish 717 meal with poultry by-product meal in diets for Black Sea turbot Psetta maeotica. $718 \quad$ Aquacult. Nutr., 12, 340-347.

719 Yones, A.M.M., \& Metwalli, A.A. (2016). Effects of Fish Meal Substitution with Poultry By720 product Meal on Growth Performance, Nutrients Utilization and Blood Contents of 721 Juvenile Nile Tilapia (Oreochromis niloticus). Journal of Aquaculture Research \& 722 Development. DOI. org/10.4172/2155-9546.1000389

723 Yu, Y. (2008). Replacement of fish meal with poultry by-product meal and hydrolyzed feather 724 meal in feeds for finfish. In: Lim, Chhorn, Webster, Carl. D. Lee, Cheng-Sheng (Eds), 725 Alternative protein sources in aquaculture diets. The Haworth Press, New York, pp. 51-93. 726 
1 Table 1 Proximate composition and essential amino acid profile of the test ingredients was used in

2 Trials 1 and $2 \mathrm{~g} \mathrm{~kg}^{-1}$ based on dry matter

Experimental ingridients

\begin{tabular}{llllll}
\hline FMLT94 $^{1}$ & EFM $^{2}$ & SDHM $^{3}$ & PMM $^{2}$ & dPMM $^{2}$ & SBM $^{1}$
\end{tabular}

Proximate composition

Dry matter

926.0

899.0

908.0

$941.0 \quad 947.0 \quad 878.0$

Crude protein

730.0

811.0

909.0

$620.0 \quad 700.0$

500.0

Crude lipid

119.0

63.0

28.0

166.0

57.0

8.0

Gross energy ( $\mathrm{MJ} \mathrm{Kg}^{-1}$ )

21.2

22.9

22.2

20.9

20.2

19.6

Ash

133.0

22.0

31.0

170.0

157.0

73.0

EAA composition*

Arginine

41.40

36.60

36.90

41.70

39.30

36.50

Histidine

17.30

7.70

69.00

11.40

10.70

7.70

Isoleucine

25.60

19.50

5.50

18.20

17.10

21.30

Leucine

50.40

39.10

123.30

43.50

41.00

36.40

Lysine

52.50

26.00

82.80

38.30

36.10

30.90

Threonine

31.00

23.70

33.10

25.60

24.10

19.00

Tryptophan

6.90

7.90

11.00

5.50

5.10

7.00

Valine

31.60

28.00

84.70

28.60

27.00

25.40

Methionine

19.50

8.20

7.40

10.00

9.40

6.90

Phenylalanine

27.70

22.20

65.40

23.10

21.70

24.40

$\operatorname{aDCP}{ }^{\sharp}(\%)$

87.50

21.70

82.80

79.20

79.20

87.00

$3 \quad{ }^{1}$ Skretting Ltd, Longridge, Preston, Lancashire, UK

$4 \quad{ }^{2}$ Prosper De Mülder Group, Market Harborough, UK

$5 \quad{ }^{3}$ American Protein Corporation (APC), Ankeny, Iowa, USA

$6 *$ Manufacturer specifications

$7 \quad \mathrm{aDCP}^{\ddagger}=$ Apparent digestibility crude protein 
10 Table 2 Formulation, proximate composition $\left(\mathrm{g} \mathrm{kg}^{-1}\right)$, essential amino acid profile of the experimental diets $\left(\mathrm{g}^{16} \mathrm{~g}^{-1}\right.$ $11 \mathrm{~N})$ and essential amino acid requirements $\left(\mathrm{g} 16 \mathrm{~g}^{-1} \mathrm{~N}\right)$ in Trial \#1.

\begin{tabular}{|c|c|c|c|c|c|c|c|}
\hline & \multicolumn{6}{|c|}{ Experimental diets } & \multirow{2}{*}{ Requirement ${ }^{10}$} \\
\hline & FM & PMM25 & PMM50 & PMM75 & EFM5 & SDHM10 & \\
\hline Fish meal LT94 $^{1}$ & 640.0 & 480.0 & 320.0 & 160.0 & 608.0 & 576.0 & \\
\hline Poultry meat meal $^{2}$ & 0.0 & 190.0 & 380.0 & 570.0 & 0.0 & 0.0 & \\
\hline Enzyme treated feather meal $^{2}$ & 0.0 & 0.0 & 0.0 & 0.0 & 108.0 & 0.0 & \\
\hline Spray-dried haemoglobin meal ${ }^{3}$ & 0.0 & 0.0 & 0.0 & 0.0 & 0.0 & 68.0 & \\
\hline Marine fish oil & 74.0 & 67.7 & 62.2 & 56.7 & 70.0 & 79.5 & \\
\hline Starch $^{4}$ & 113.3 & 113.3 & 113.3 & 113.3 & 113.3 & 113.3 & \\
\hline Dextrin $^{5}$ & 56.7 & 56.7 & 56.7 & 56.7 & 56.7 & 56.7 & \\
\hline Vitamin 6 & 5.0 & 5.0 & 5.0 & 5.0 & 5.0 & 5.0 & \\
\hline Mineral $^{7}$ & 5.0 & 5.0 & 5.0 & 5.0 & 5.0 & 5.0 & \\
\hline Cellulose $^{8}$ & 106.0 & 82.3 & 57.8 & 33.3 & 34.0 & 96.5 & \\
\hline \multicolumn{8}{|l|}{ Proximate composition } \\
\hline Dry matter & 965.70 & 961.80 & 952.10 & 953.70 & 961.80 & 963.30 & \\
\hline Crude protein & 460.80 & 467.70 & 486.20 & 530.50 & 489.70 & 474.40 & \\
\hline Crude lipid & 121.50 & 114.10 & 126.50 & 140.60 & 144.00 & 180.10 & \\
\hline Gross energy (MJ Kg ${ }^{-1}$ ) & 20.44 & 20.57 & 20.61 & 20.82 & 21.80 & 20.92 & \\
\hline Ash & 94.80 & 102.40 & 108.10 & 97.30 & 112.60 & 92.60 & \\
\hline \multicolumn{8}{|l|}{ Essential Amino acid profile ${ }^{9}$} \\
\hline Arginine & $\begin{array}{c}2.91 * \\
(6.31)^{+}\end{array}$ & $2.97(6.35)$ & $3.04(6.25)$ & $3.10(5.85)$ & $3.16(6.44)$ & $3.04(6.41)$ & 5.55 \\
\hline Histidine & $1.06(2.29)$ & $1.01(2.16)$ & $0.96(1.98)$ & $0.91(1.72)$ & $1.09(2.22)$ & $1.38(2.90)$ & 1.98 \\
\hline Isoleucine & $2.00(4.35)$ & $1.85(3.95)$ & $1.69(3.48)$ & $1.54(2.90)$ & $2.11(4.32)$ & $1.84(3.87)$ & 2.55 \\
\hline Leucine & $3.32(7.21)$ & $3.32(7.09)$ & $3.31(6.82)$ & $3.31(6.24)$ & $3.58(7.31)$ & $3.75(7.91)$ & 4.75 \\
\hline Lysine & $3.56(7.74)$ & $3.40(7.27)$ & $3.24(6.66)$ & $3.07(5.80)$ & $3.67(7.49)$ & $3.72(7.84)$ & 5.13 \\
\hline Threonine & $1.86(4.03)$ & $1.88(4.02)$ & $1.90(3.91)$ & $1.92(3.63)$ & $2.02(4.12)$ & $1.87(3.95)$ & 2.89 \\
\hline Tryptophan & $0.49(1.07)$ & $0.47(1.01)$ & $0.46(0.94)$ & $0.44(0.82)$ & $0.55(1.13)$ & $0.51(5.36)$ & 0.75 \\
\hline Valine & $2.75(5.97)$ & $2.61(5.57)$ & $2.46(5.07)$ & $2.32(4.37)$ & $2.92(5.96)$ & $3.00(3.63)$ & 3.21 \\
\hline Methionine & $1.33(2.89)$ & $1.19(2.54)$ & $1.05(2.15)$ & $0.90(1.70)$ & $1.35(2.76)$ & $1.24(2.62)$ & 2.60 \\
\hline Phenylalanine & $1.73(3.76)$ & $1.74(3.72)$ & $1.75(3.59)$ & $1.75(3.30)$ & $1.89(3.85)$ & $1.97(4.14)$ & $5.76^{11}$ \\
\hline
\end{tabular}


$12{ }^{1}$ Skretting Ltd. Longridge, Preston, Lancashire, UK

$13{ }^{2}$ Prosper De Mülder Group, Market Harborough. UK

$14{ }^{3}$ American Protein Corporation (APC), Ankeny, Iowa, USA

$15{ }^{4}$ Starch from corn (Sigma S4126)

$16{ }^{5}$ Dextrin type II from corn (Sigma D2130)

$17{ }^{6}$ Sigma-Aldrich Chemical.

$18{ }^{7}$ Skretting Aquaculture, Longridge Preston, UK.

$19{ }^{8}$ Sigma (C8002)

$20{ }^{9}$ Calculated

$21{ }^{10}$ Peres and Oliva-Teles (2007)

$22 \quad{ }^{11}$ Phenylalanine + tyrosine.

$23 *$ Percentage of the diet.

$24+$ Percentage of the protein. 
26 Table 3 Formulation, proximate composition $\left(\mathrm{g} \mathrm{kg}^{-1}\right)$, essential amino acid profile of the experimental diets $\left(\mathrm{g}^{16} \mathrm{~g}^{-1}\right.$

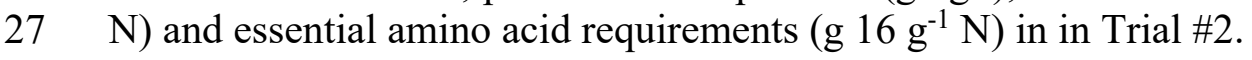

\begin{tabular}{|c|c|c|c|c|c|c|}
\hline & \multicolumn{5}{|c|}{ Experimental diets } & \multirow{2}{*}{ Requirement $^{10}$} \\
\hline & FM & PMM75 & dPMM50 & dPMM75 & SBM/dPMM & \\
\hline Fish meal LT94 ${ }^{1}$ & 640.0 & 160.0 & 320.0 & 160.0 & 320.0 & \\
\hline Poultry meat meal $^{2}$ & 0.0 & 570.0 & 0.0 & 0.0 & 0.0 & \\
\hline Defatted poultry meat meal ${ }^{2}$ & 0.0 & 0.0 & 333.0 & 495.0 & 194.0 & \\
\hline Soybean meal (de-hulled) ${ }^{3}$ & 0.0 & 0.0 & 0.0 & 0.0 & 194.0 & \\
\hline Marine fish oil & 73.0 & 57.0 & 100.0 & 110.0 & 100.0 & \\
\hline Starch $^{4}$ & 113.0 & 113.0 & 113.0 & 113.0 & 113.0 & \\
\hline Dextrin $^{5}$ & 57.0 & 57.0 & 57.0 & 57.0 & 57.0 & \\
\hline Vitamin 6 & 5.0 & 5.0 & 5.0 & 5.0 & 5.0 & \\
\hline $\operatorname{Mineral}^{7}$ & 5.0 & 5.0 & 5.0 & 5.0 & 5.0 & \\
\hline Additive (Vitamin C) & 1.0 & 1.0 & 1.0 & 1.0 & 1.0 & \\
\hline Cellulose $^{8}$ & 106.0 & 32.0 & 66.0 & 54.0 & 11.0 & \\
\hline \multicolumn{7}{|l|}{ Proximate composition } \\
\hline Moisture & 865.80 & 886.50 & 860.70 & 873.10 & 877.70 & \\
\hline Crude protein & 456.70 & 476.50 & 460.80 & 454.40 & 454.80 & \\
\hline Crude lipid & 114.70 & 148.20 & 114.10 & 131.30 & 133.00 & \\
\hline Gross energy (MJ Kg ${ }^{-1}$ ) & 16.86 & 17.54 & 16.60 & 17.14 & 17.32 & \\
\hline Ash & 83.70 & 110.30 & 97.40 & 100.80 & 87.80 & \\
\hline \multicolumn{7}{|l|}{ Essential Amino acid profile ${ }^{9}$} \\
\hline Arginine & $2.91 *(6.31)^{+}$ & $3.10(6.51)$ & $2.76(5.99)$ & $2.67(5.88)$ & $2.92(6.43)$ & 5.55 \\
\hline Histidine & $1.06(2.29)$ & $0.91(2.00)$ & $0.88(1.92)$ & $0.79(1.75)$ & $0.98(2.15)$ & 1.98 \\
\hline Leucine & $3.32(7.21)$ & $3.31(7.25)$ & $3.03(6.57)$ & $2.86(6.29)$ & $3.16(6.95)$ & 4.75 \\
\hline Lysine & $3.56(7.74)$ & $3.07(6.73)$ & $2.98(6.48)$ & $2.68(5.89)$ & $3.08(6.78)$ & 5.13 \\
\hline Threonine & $1.86(4.03)$ & $1.92(4.21)$ & $1.73(3.76)$ & $1.66(3.65)$ & $1.76(3.88)$ & 2.89 \\
\hline Tryptophan & $0.49(1.07)$ & $0.44(0.96)$ & $0.42(0.90)$ & $0.38(0.83)$ & $0.48(1.06)$ & 0.75 \\
\hline Valine & $2.75(5.97)$ & $2.32(5.08)$ & $2.28(4.94)$ & $2.02(4.46)$ & $2.39(5.26)$ & 3.21 \\
\hline Methionine & $1.33(2.89)$ & $0.90(1.98)$ & $0.98(2.12)$ & $0.80(1.76)$ & $0.98(2.16)$ & 2.60 \\
\hline Phenylalanine & $1.73(3.76)$ & $1.75(3.83)$ & $1.59(3.45)$ & $1.51(3.32)$ & $1.76(3.87)$ & $5.76^{11}$ \\
\hline
\end{tabular}


$28{ }^{1}$ Skretting Ltd. Longridge, Preston, Lancashire, UK.

292 Prosper De Mülder Group, Market Harborough, UK.

$30{ }^{3}$ American Protein Corporation (APC), Ankeny, Iowa, USA.

$31{ }^{4}$ Starch from corn (Sigma S41126).

$32{ }^{5}$ Dextrin type II from corn (Sigma D2130).

$33{ }^{6}$ Sigma-Aldrich Chemical.

$34{ }^{7}$ Skretting Aquaculture, Longridge Preston, UK.

\section{$35{ }^{8}$ Sigma (C8002).}

$36{ }^{9}$ Calculated.

$37 \quad{ }^{10}$ Peres and Oliva-Teles (2007).

$38 \quad{ }^{11}$ Phenylalanine + tyrosine.

$39 *$ Percentage of the diet.

$40+$ Percentage of the protein. 
41 Table 4 Growth performances, feed utilization parameters and proximate composition of gilthead sea bream fed the

42 experimental diets of Trial 1 (means $\pm \mathrm{SE}$ ).

\begin{tabular}{|c|c|c|c|c|c|c|c|c|}
\hline & \multicolumn{6}{|c|}{ Experimental diets } & \multirow{2}{*}{$\pm \mathrm{SEM}$} \\
\hline & & FM & PMM25 & PMM50 & PMM75 & EFM5 & SDHM10 & \\
\hline \multicolumn{9}{|l|}{ Growth performance } \\
\hline \multicolumn{2}{|l|}{ Initial weight (g) } & $22.85 \pm 0.54$ & $22.42 \pm 0.28$ & $22.67 \pm 0.29$ & $22.91 \pm 0.21$ & $22.67 \pm 0.32$ & $22.66 \pm 0.53$ & 0.17 \\
\hline \multicolumn{2}{|l|}{ Final weight (g) } & $67.75 \pm 0.55^{\mathrm{abc}}$ & $68.99 \pm 1.16^{\mathrm{abc}}$ & $63.87 \pm 0.14^{\mathrm{ab}}$ & $63.58 \pm 2.18^{a}$ & $69.77 \pm 0.40^{\mathrm{bc}}$ & $70.69 \pm 1.47^{\mathrm{c}}$ & 3.04 \\
\hline \multicolumn{2}{|l|}{ Weight gain (g) } & $44.88 \pm 0.02^{\mathrm{abc}}$ & $46.57 \pm 1.44^{\mathrm{abc}}$ & $41.20 \pm 0.15^{\mathrm{ab}}$ & $40.67 \pm 2.05^{\mathrm{a}}$ & $47.10 \pm 0.26^{\mathrm{bc}}$ & $48.03 \pm 1.52^{\mathrm{c}}$ & 3.13 \\
\hline \multicolumn{2}{|l|}{ Weight gain $(\%)^{1}$} & $195.5 \pm 4.57^{\mathrm{ab}}$ & $207.8 \pm 9.02^{\mathrm{ab}}$ & $181.9 \pm 3.00^{\mathrm{ab}}$ & $177.4 \pm 8.10^{\mathrm{a}}$ & $207.9 \pm 3.24^{\mathrm{ab}}$ & $212.2 \pm 9.37^{\mathrm{b}}$ & 14.70 \\
\hline \multicolumn{2}{|l|}{ Feed intake ( $\mathrm{g} \mathrm{fish}^{-1}$ day $\left.^{-1}\right)$} & $1.02 \pm 0.02^{\mathrm{b}}$ & $0.98 \pm 0.03^{\mathrm{ab}}$ & $0.91 \pm 0.01^{\mathrm{ab}}$ & $0.89 \pm 0.04^{\mathrm{a}}$ & $0.98 \pm 0.01^{\mathrm{ab}}$ & $0.99 \pm 0.02^{\mathrm{ab}}$ & 0.05 \\
\hline \multicolumn{2}{|l|}{$\operatorname{SGR}\left(\% \text { day }^{-1}\right)^{2}$} & $1.72 \pm 0.02^{\mathrm{ab}}$ & $1.78 \pm 0.05^{\mathrm{ab}}$ & $1.64 \pm 0.02^{\mathrm{ab}}$ & $1.62 \pm 0.05^{\mathrm{a}}$ & $1.78 \pm 0.02^{\mathrm{ab}}$ & $1.80 \pm 0.05^{\mathrm{b}}$ & 0.08 \\
\hline \multicolumn{2}{|l|}{$\mathrm{FCR}^{3}$} & $1.43 \pm 0.02^{\mathrm{c}}$ & $1.33 \pm 0.01^{\mathrm{ab}}$ & $1.39 \pm 0.02^{\mathrm{bc}}$ & $1.37 \pm 0.01^{\mathrm{bc}}$ & $1.32 \pm 0.02^{\mathrm{ab}}$ & $1.30 \pm 0.02^{\mathrm{a}}$ & 0.05 \\
\hline \multirow{2}{*}{\multicolumn{2}{|c|}{$\begin{array}{l}\text { PER }^{4} \\
\text { aNPU }(\%)^{5}\end{array}$}} & $1.52 \pm 0.02^{\mathrm{b}}$ & $1.60 \pm 0.01^{\mathrm{bc}}$ & $1.48 \pm 0.02^{\mathrm{b}}$ & $1.37 \pm 0.01^{\mathrm{a}}$ & $1.55 \pm 0.02^{\mathrm{bc}}$ & $1.62 \pm 0.02^{\mathrm{c}}$ & 0.09 \\
\hline & & $21.40 \pm 0.65^{\mathrm{a}}$ & $22.19 \pm 0.63^{\mathrm{a}}$ & $21.42 \pm 2.89^{\mathrm{a}}$ & $22.43 \pm 3.62^{\mathrm{a}}$ & $22.78 \pm 1.14^{\mathrm{a}}$ & $23.62 \pm 4.17^{\mathrm{a}}$ & 0.85 \\
\hline & Initial & FM & PMM25 & PMM50 & PMM75 & EFM5 & SDHM10 & \multirow{2}{*}{$\pm \mathrm{SEM}$} \\
\hline \multicolumn{8}{|l|}{ Carcass composition $\mathrm{g} \mathrm{kg}^{-1}$} & \\
\hline Moisture & $686.0 \pm 0.24$ & $676.2 \pm 0.13$ & $663.2 \pm 0.54$ & $670.8 \pm 1.84$ & $662.4 \pm 1.77$ & $676.5 \pm 0.05$ & $668.5 \pm 1.85$ & 0.83 \\
\hline Crude protein & $522.4 \pm 0.08$ & $420.1 \pm 0.84$ & $397.6 \pm 1.35$ & $409.5 \pm 1.11$ & $412.3 \pm 1.55$ & $415.4 \pm 1.11$ & $407.4 \pm 2.43$ & 4.29 \\
\hline Crude lipid & $336.4 \pm 0.65$ & $285.9 \pm 0.96$ & $304.7 \pm 0.39$ & $293.2 \pm 1.48$ & $290.3 \pm 0.50$ & $274.5 \pm 0.48$ & $290.8 \pm 0.66$ & 1.97 \\
\hline Ash & $105.0 \pm 0.14$ & $83.7 \pm 0.03$ & $82.7 \pm 0.21$ & $84.2 \pm 0.30$ & $86.5 \pm 0.47$ & $83.9 \pm 0.40$ & $84.1 \pm 0.53$ & 0.80 \\
\hline Gross energy $\left(\mathrm{MJ} \mathrm{Kg}^{-1}\right)$ & $25.03 \pm 0.00$ & $20.04 \pm 0.99$ & $20.92 \pm 0.34$ & $20.44 \pm 0.43$ & $19.95 \pm 0.23$ & $19.99 \pm 0.38$ & $20.34 \pm 0.70$ & 1.83 \\
\hline
\end{tabular}

Values are presented as means of three replicates \pm SE. One-way Anova with Tukey's pair wise comparison test $(\dagger)$ or

Kruskal Wallis's test with post hoc multiple comparison testing $(\$)$ in the case of a lake of normality in the data set were

utilized to reveal significant differences between treatments. In each row, values with the same superscripts are not

significantly different $(P>0.05)$.

${ }^{1}$ Weight gain $(\%)=100 \times($ mean final weight - mean initial weight $) /$ men initial weight.

${ }^{2}$ FCR: feed intake / weight gain.

${ }^{3}$ SGR: $100 \times[(\ln$ mean final weight-ln mean initial weight $) /$ days $]$.

${ }^{4}$ PER: mean weight gain / mean protein intake.

5 aNPU: $100 \times$ (protein deposition / digestible protein intake). 
Table 5 Morphometric measurements and general haematological indices of gilthead sea bream assessed on termination of Trial 1

(means $\pm \mathrm{SE}$ ).

\begin{tabular}{|c|c|c|c|c|c|c|c|}
\hline & \multicolumn{6}{|c|}{ Experimental diets } & \multirow{2}{*}{$\pm \mathrm{SEM}$} \\
\hline & FM & PMM25 & PMM50 & PMM75 & EFM5 & SDHM10 & \\
\hline \multicolumn{8}{|l|}{ General morphometry } \\
\hline Condition factor $(\mathrm{K})^{1}$ & $2.06 \pm 0.02$ & $2.08 \pm 0.00$ & $2.09 \pm 0.03$ & $2.11 \pm 0.03$ & $2.08 \pm 0.02$ & $2.10 \pm 0.03$ & 0.02 \\
\hline Hepatosomatic index $(\%)^{2}$ & $1.32 \pm 0.28$ & $1.41 \pm 0.03$ & $1.35 \pm 0.03$ & $1.36 \pm 0.13$ & $1.30 \pm 0.08$ & $1.35 \pm 0.04$ & 0.04 \\
\hline Haematocrit (\%) & $39.00 \pm 1.80$ & $36.50 \pm 1.90$ & $38.53 \pm 3.71$ & $41.97 \pm 1.30$ & $39.33 \pm 2.76$ & $37.05 \pm 2.05$ & 1.94 \\
\hline Haemoglobin $\left(\mathrm{g} \mathrm{dL}^{-1}\right)$ & $7.65 \pm 0.60$ & $7.24 \pm 0.11$ & $7.72 \pm 0.99$ & $7.63 \pm 0.24$ & $7.74 \pm 0.12$ & $7.81 \pm 0.12$ & 0.20 \\
\hline $\mathrm{RBCC}\left(\times 10^{6} \mathrm{~mm}^{-3}\right)$ & $2.40 \pm 0.20$ & $2.20 \pm 0.13$ & $2.73 \pm 0.44$ & $2.59 \pm 0.13$ & $2.71 \pm 0.14$ & $2.34 \pm 0.15$ & 0.22 \\
\hline
\end{tabular}

54 Values are presented as means of three replicates \pm SE. One-way Anova with Tukey's pairwise comparison test or 55 Kruskal Wallis's test with post hoc multiple comparison testing in the case of a lake of normality in the data set were 56 utilized to reveal significant differences between treatments. In each row, values with the same superscripts are not 57 significantly different $(P>0.05)$.

$58{ }^{1} \mathrm{~K}:($ fish weight $(\mathrm{g}) \times 100) /(\text { fish length }(\mathrm{cm}))^{3}$.

$59{ }^{2}$ Hepatosomatic index: $100 \times$ (liver weight / whole body weight). 
61 Table 6 Growth performances, feed utilization parameters and proximate composition of gilthead sea bream fed the experimental 62 diets of Trial 2 (means \pm SE).

\begin{tabular}{|c|c|c|c|c|c|c|c|}
\hline & & \multicolumn{5}{|c|}{ Experimental diets } & \multirow{2}{*}{$\pm \mathrm{SEM}$} \\
\hline & & FM & PMM75 & dPMM50 & dPMM75 & $\mathrm{SBM} / \mathrm{Dpmm}$ & \\
\hline \multicolumn{8}{|l|}{ Growth performance } \\
\hline Initial weight $(\mathrm{g}) \dagger$ & & $10.07 \pm 0.06$ & $10.08 \pm 0.05$ & $9.92 \pm 0.14$ & $10.14 \pm 0.07$ & $10.19 \pm 0.10$ & 0.10 \\
\hline Final weight $(\mathrm{g}) \dagger$ & & $35.31 \pm 1.23^{\mathrm{b}}$ & $31.32 \pm 0.50^{\mathrm{a}}$ & $33.35 \pm 0.16^{\mathrm{ab}}$ & $30.95 \pm 0.46^{\mathrm{a}}$ & $33.67 \pm 0.38^{\mathrm{ab}}$ & 1.80 \\
\hline Weight gain $(\%)^{1} \dagger$ & & $250.6 \pm 13.2^{\mathrm{b}}$ & $210.7 \pm 6.6^{\mathrm{a}}$ & $236.5 \pm 6.2^{\mathrm{ab}}$ & $205.4 \pm 5.2^{\mathrm{a}}$ & $230.3 \pm 1.9^{\mathrm{b}}$ & 18.61 \\
\hline Feed intake $\left(\mathrm{g} \mathrm{fish}^{-1}\right.$ day $\left.^{-1}\right)$ & & $1.39 \pm 0.01^{\mathrm{a}}$ & $0.98 \pm 0.02^{\mathrm{b}}$ & $1.14 \pm 0.03^{\mathrm{ab}}$ & $0.98 \pm 0.03^{b}$ & $1.01 \pm 0.03^{\mathrm{ab}}$ & 0.18 \\
\hline $\operatorname{SGR}\left(\% \text { day }^{-1}\right)^{2} \dagger$ & & $3.58 \pm 0.10^{\mathrm{b}}$ & $3.24 \pm 0.06^{\mathrm{a}}$ & $3.47 \pm 0.05^{\mathrm{ab}}$ & $3.19 \pm 0.05^{\mathrm{a}}$ & $3.41 \pm 0.01^{\mathrm{ab}}$ & 0.16 \\
\hline $\mathrm{FCR}^{3 \dagger}$ & & $1.93 \pm 0.07^{\mathrm{b}}$ & $1.62 \pm 0.01^{\mathrm{a}}$ & $1.71 \pm 0.06^{\mathrm{ab}}$ & $1.65 \pm 0.03^{\mathrm{a}}$ & $1.50 \pm 0.05^{\mathrm{a}}$ & 0.30 \\
\hline $\mathrm{PER}^{4} \dagger$ & & $1.12 \pm 0.04^{\mathrm{a}}$ & $1.28 \pm 0.01^{\mathrm{abc}}$ & $1.26 \pm 0.04^{\mathrm{ab}}$ & $1.31 \pm 0.03^{\mathrm{bc}}$ & $1.45 \pm 0.05^{\mathrm{c}}$ & 0.12 \\
\hline \multirow[t]{2}{*}{$\operatorname{aNPU}(\%)^{5} \dagger$} & & $21.64 \pm 0.88^{\mathrm{a}}$ & $25.43 \pm 0.16^{\mathrm{bc}}$ & $22.71 \pm 0.59^{\mathrm{ab}}$ & $24.77 \pm 0.45^{\mathrm{abc}}$ & $27.76 \pm 1.24^{\mathrm{c}}$ & 2.61 \\
\hline & Initial & FM & PMM75 & dPMM50 & dPMM75 & SBM/dPMM & \multirow{2}{*}{$\pm \mathrm{SEM}$} \\
\hline \multicolumn{7}{|l|}{ Carcass composition $\mathrm{g} \mathrm{kg}^{-1}$} & \\
\hline Moisture & $706.0 \pm 0.4$ & $693.0 \pm 0.5$ & $700.0 \pm 0.5$ & $708.0 \pm 0.9$ & $696.0 \pm 0.1$ & $689.0 \pm 0.2$ & 0.74 \\
\hline Crude protein & $486.0 \pm 0.2$ & $521.0 \pm 0.7$ & $526.0 \pm 0.8$ & $521.0 \pm 0.4$ & $514.0 \pm 0.1$ & $510.0 \pm 0.3$ & 1.44 \\
\hline Crude lipid & $217.0 \pm 1.3$ & $296.0 \pm 1.6$ & $293.0 \pm 1.2$ & $310.0 \pm 0.2$ & $308.0 \pm 0.1$ & $310.0 \pm 0.8$ & 3.60 \\
\hline Ash & $133.0 \pm 0.1$ & $108.0 \pm 0.2^{b}$ & $122.0 \pm 0.4^{\mathrm{a}}$ & $118.0 \pm 0.1^{\mathrm{ab}}$ & $121.0 \pm 0.3^{\mathrm{a}}$ & $112.0 \pm 0.1^{\mathrm{ab}}$ & 0.78 \\
\hline Gross energy $\left(\mathrm{MJ} \mathrm{Kg}^{-1}\right)$ & $22.1 \pm 0.0$ & $25.4 \pm 0.2$ & $24.8 \pm 0.2$ & $25.1 \pm 0.1$ & $25.1 \pm 0.1$ & $25.4 \pm 0.1$ & 1.27 \\
\hline
\end{tabular}

63 Values are presented as means of three replicates \pm SE. One-way Anova with Tukey's pairwise comparison test ( $\dagger)$ or 64 Kruskal Wallis's test with post hoc multiple comparison testing $(+)$ in the case of a lake of normality in the data set were 65 utilized to reveal significant differences between treatments. In each row, values with the same superscripts are not 66 significantly different $(P>0.05)$.

$67{ }^{1}$ Weight gain $(\%)=100 \times($ mean final weight - mean initial weight $) /$ men initial weight.

68 2 FCR: feed intake / weight gain.

$69{ }^{3}$ SGR: $100 \times[(\ln$ mean final weight-ln mean initial weight $) /$ days $]$.

$70 \quad{ }^{4}$ PER: mean weight gain / mean protein intake.

715 aNPU: $100 \times$ (protein deposition / digestible protein intake). 
Table 7 Fatty acid composition of experimental diets and resulting carcasses (expressed as weight percent of total fatty

74 acid) of gilthead sea bream fed the experimental diets of Trial 2 (means \pm SE).

\begin{tabular}{|c|c|c|c|c|c|c|c|c|}
\hline & \multicolumn{3}{|l|}{ Diets } & \multirow{2}{*}{ \pm SEM } & \multicolumn{3}{|l|}{ Carcasses } & \multirow{2}{*}{$\pm \mathrm{SEM}$} \\
\hline & $\mathrm{FM}$ & PMM75 & dPMM75 & & FM & PMM75 & dPMM75 & \\
\hline $14: 0$ & 9.0 & 4.3 & 7.6 & 2.41 & $5.2 \pm 0.1$ & $3.4 \pm 0.1$ & $5.0 \pm 0.1$ & 0.99 \\
\hline $16: 0$ & 23.4 & 24.6 & 24.3 & 0.62 & $18.7 \pm 0.2$ & $19.4 \pm 0.6$ & $19.0 \pm 0.2$ & 5.46 \\
\hline $18: 0$ & 3.7 & 6.1 & 5.5 & 1.25 & $3.6 \pm 0.1$ & $4.3 \pm 0.2$ & $3.5 \pm 0.6$ & 0.44 \\
\hline Total SFA & 40.4 & 38.1 & 41.8 & 1.87 & 31.1 & 30.0 & 31.2 & 0.67 \\
\hline $16: 1 n-7$ & 11.4 & 8.2 & 10.5 & 1.65 & $9.4 \pm 0.1$ & $8.6 \pm 0.1$ & $9.8 \pm 0.1$ & 0.61 \\
\hline $18: \ln -9$ & 18.7 & 32.9 & 24.3 & 7.16 & $20.5 \pm 0.4$ & $30.1 \pm 0.9$ & $23.1 \pm 0.2$ & 4.97 \\
\hline $20: 1 n-9$ & 9.2 & 3.4 & 3.7 & 3.27 & $5.3 \pm 0.1$ & $2.7 \pm 0.1$ & $2.7 \pm 0.0$ & 1.50 \\
\hline $22: 1 n-11$ & 9.3 & 2.4 & 2.9 & 3.85 & $4.9 \pm 0.1$ & $2.1 \pm 0.1$ & $2.3 \pm 0.1$ & 1.56 \\
\hline Total MUFA & 49.5 & 47.5 & 42.5 & 3.61 & 41.4 & 44.4 & 39.1 & 2.66 \\
\hline $18: 2 n-6$ & 1.0 & 6.7 & 4.4 & 2.87 & $2.4 \pm 0.2$ & $8.8 \pm 0.1$ & $5.2 \pm 0.1$ & 3.21 \\
\hline $20: 4 n-6$ & 0.1 & 0.2 & 0.3 & 0.10 & $0.6 \pm 0.0$ & $0.6 \pm 0.0$ & $0.7 \pm 0.0$ & 0.06 \\
\hline Total n-6 & 1.7 & 7.6 & 5.6 & 3.00 & 4.8 & 11.0 & 7.7 & 3.10 \\
\hline $18: 3 n-3$ & 0.4 & 0.7 & 0.8 & 0.21 & $0.8 \pm 0.1$ & $1.5 \pm 0.1$ & $1.2 \pm 0.1$ & 0.35 \\
\hline $18: 4 n-3$ & 0.3 & 0.2 & 0.6 & 0.20 & $1.5 \pm 0.1$ & $1.0 \pm 0.0$ & $1.4 \pm 0.1$ & 0.27 \\
\hline $20: 5 n-3$ & 1.4 & 0.8 & 2.3 & 0.75 & $7.5 \pm 0.2$ & $4.0 \pm 0.1$ & $6.0 \pm 0.2$ & 1.76 \\
\hline $22: 5 n-3$ & 0.1 & 0.3 & 0.5 & 0.20 & $2.1 \pm 0.1$ & $1.3 \pm 0.1$ & $1.6 \pm 0.1$ & 0.40 \\
\hline $22: 6 n-3$ & 1.9 & 0.9 & 1.9 & 0.58 & $10.5 \pm 0.4$ & $5.4 \pm 0.2$ & $6.8 \pm 0.1$ & 2.64 \\
\hline Total n-3 & 4.3 & 3.1 & 6.4 & 1.67 & 23.3 & 13.7 & 17.7 & 4.82 \\
\hline Total PUFA & 6.0 & 10.7 & 12.0 & 3.16 & 28.1 & 24.7 & 25.4 & 1.80 \\
\hline Ratio n-3/n-6 & 2.53 & 0.41 & 1.14 & 1.08 & 4.8 & 1.2 & 2.3 & 0.78 \\
\hline
\end{tabular}

